From the literary point of view, it is a relief to read that "although Basic is clear and precise at the level for which it is intended ", it has no literary claims. It seems to discard most of the canons of good style, for example, to prefer the concrete to the abstract, and to use the single word in prefer. ence to the circumlocution. The author has little use for "the antic haverings of a pedantic pedestrianism in quest of Pure English" ; so he allows us cheerfully to mix up 'shall' and 'will', to use noun-adjectives $a d l i b$., and to end a sentence with a preposition.

The fact that Basic has no literary pretensions and is yet recommended as the I.A.L. for science, suggests that its author has a poor opinion of the literary value of scientific writing. If so, he is not alone; but if present-day style in scientific writing is generally poor, it is at least preferable to that of Basic. A style that is both concise and precise is indispensable to good scientific writing, and the scientific author who uses two words where one would suffice, is as much a malefactor as the man who makes two blades grow where one grew before is a benefactor to his kind. Although $\mathrm{Mr}$. Ogden realises that a much larger vocabulary is needed for science than for more mundane purposes, it seems certain that many more nouns would be required than he contemplates. As in other national languages, the resources of English are proving more and more inadequate to keep pace with the multiplication of new concepts, so that science would appear to need an I.A.L. possessing a vocabulary of constructed words that would allow of constant and regular expansion, rather than a language like Basic the chief aim of which is to restrict the vocabulary to the smallest possible number of words. What is sauce to the Kafir is not necessarily sauce to the chemist.

In "Basic English Applied (Science)", Basic versions are given of three scientific communications: a paper from the Journal of the Chemical Society on the analysis of light oils and motor spirits; a lecture on the mathematical problem of aerodynamies; a letter to NATURE (123, 601;
1929) on spectrographic analysis of animal tissues ; and a few abstracts of patents taken from the Nickel Bulletin. Lack of space precludes a detailed appreciation of these efforts, and it must suffice to say that in the writer's opinion the translator has succeeded in making his translations generally intelligible, but that the 'wordiness', the frequent lack of precision, and the frequently curious phraseology all combine to make one hope that scientific English will never descend "to the level for which Basic is designed ". The following are some examples in which Basic wording (given in italics) is held to be deficient: Desiccator-drying vessel; retort-heating apparatus; alloy-mixed metal; boiling-.-at vapour temperature; evolution - development; describe-give details of ; distilgive a distillation; viscous-fluid flow-motion in liquid or gaseous mediums. The method has been developed quantitatively-By an expansion of the method it is possible to get the amount of the elements present. A detailed account of the work will be published shortly- $A$ detailed account of the work will be printed shortly.

The somewhat unconventional ending to one paper, "It was very kind of the Director of Fuel Research to let the writer put this paper into print", prompts the present writer to sum up his conclusions as follows : It was very kind of the Editor of NATURE to let the writer have these books and give his opinions of them; they are bright (clever) and interesting and in places they give amusement; but they do not give him strong belief (convince him). Though he is of the opinion that the new language (old wine in a new vessel) will be of use to men of other countries when they make a start to learn our language, he has the hope and makes the request to a Higher Being (prays) that it may at no time come into use for Letters or for Science. It might make better the language of trade; it is almost not possible to make it worse.

In making this attempt at 'an attempt', the reviewer was surprised and perplexed not to find the word "Basic" in the 850 -word vocabulary, either among the 400 " necessary names" or the 200 "common things". Is this an omen?

\title{
Obituary
}

\section{Prof. Roland Thaxter}

$\mathrm{P}$ ROF. ROLAND THAXTER, of Harvard, died on April 22, at the age of seventy-three years. He was born at Newton, Mass., on Aug. 28, 1858, and graduated at Harvard University in 1882 , proceeding to post-graduate work there until he was appointed mycologist at the Connecticut Experimental Station in 1888. Three years later he returned to Harvard as assistant professor of cryptogamic botany, becoming professor in 1901. He retired in 1919 with the title of emeritus professor, and acted as honorary curator of the Farlow Herbarium.

Such is the bare outline of the career of one whose work in mycology is classical. His first researches were on the rust Gymnosporangium, but he published an account of the entomogenous family Entomopthoreæ in 1888, which still remains one of the most important papers on the group. A few phytopathological reports appeared while he was at Connecticut, some of considerable interest. In 1890 he made his first contribution to our knowledge of the peculiar entomogenous fungi, the Laboulbeniaceæ, and it is with these that his name is chiefly associated, for from being almost unknown, they became, owing to Thaxter's enthusiasm, a group as well understood as any other and containing hundreds of genera and thousands of species.

Thaxter's method was to publish preliminary diagnoses of new genera and species and gather these together in monographs bearing the title "Contributions towards a Monograph of the Laboulbeniaceæ", which were illustrated with numerous plates of admirable drawings by the author. Part V. of the "Contributions " appeared this year, and he was busy preparing a sixth when he died. Some idea of the work entailed in the 
description and figures may be gained from the fact that the five parts in all run to 1185 pages and 166 plates. Probably no mycologist, with the exception of Elias Fries, has ever been identified with a group to the extent that Thaxter was with the Laboulbeniaceæ. However, he did not restrict his observations to this fascinating group, but seemed to possess an almost unhuman flair for finding fungi which he himself called "new or peculiar", and described by him occasionally throughout his career. He was, moreover, the first to recognise the anomalous group Myxobacteriaceæ which have lately come into fashion.

Thaxter's association with Prof. W. G. Farlow at Harvard was an ideal one, and together they succeeded in building up a school of cryptogamic botany and herbarium which are without rival in any university. For a number of years Thaxter suffered from ill-health, but his letters were always cheerful, even when increasing trouble with cataract made it seem probable that he would be compelled to cease work. He was somewhat critical of some of the recent tendencies in applied mycology, but his criticisms were given from the fullness of his knowledge of the subject and not from a feeling of having been left behind.

In 1907, Thaxter succeeded Farlow as American editor of the Annals of Botany, Farlow having served since its beginning in 1887 . His name was thus always prominently before British botanists. He received many distinctions; among others, he was a foreign member of the Linnean Society of London, honorary fellow of the Royal Society of Edinburgh, and honorary member of the British Mycological Society.

\section{Dr. Cuthbert Christy}

News has recently been received of the death on May 29, at sixty-eight years of age, of Dr. Cuthbert Christy, the well-known naturalist and explorer, who was engaged in scientific work for the Belgian Government in the Congo. It appears that, while in the Aka River region, he wounded a buffalo which turned and gored him, inflicting fatal injuries. He had for many years been collecting for the British Museum (Natural History), and his collections, notably those from Lakes Nyasa and Tanganyika, have proved to be of quite exceptional importance.

Dr. Christy was the son of Robert Christy of Chelmsford, and was educated at Scarborough and the University of Edinburgh, where he proceeded to take a medical degree and was appointed Mackenzie bursar in anatomy. His first travels abroad started in 1892, when for three years he travelled throughout a large part of South America and the West Indies. Some years later he was appointed Medical Officer of the 2nd Battalion West African Field Force in Northern Nigeria, and afterwards took on the duties of medical officer in India in the Bombay Plague Laboratory. In 1902 he served on the first Sleeping Sickness Commission in Africa, and at a later date was a member of the Liverpool School of Tropical Medicine
Sleeping Sickness Expedition to the Congo, and of that organised by the Sudan Government.

Dr. Christy's intimate knowledge of native life in health and disease, and his explorations in many fields, are revealed to some extent in several published works and reports, among them being "Big Game and Pygmies", "Mosquitoes and Malaria", and "The Birds of San Domingo". He was chairman of the International Commission appointed by the League of Nations to inquire into the existence of slavery and forced labour in Liberia; and the recommendations of the Commission were accepted by the Council of the League and the Liberian Government.

Between 1903 and 1910, Dr. Christy visited Ceylon and various parts of East and West Africa, all the time collecting such specimens for the Natural History Museum as came his way. From 1911 until 1914 he was engaged in scientific exploration work in the Congo, and during this period he obtained many specimens for the Museum collections.

Among the mammals collected during this period were an important collection from the neighbourhood of Avakubi, in which Dr. Christy obtained two rats new to science and a dormouse which was named after him, Graphiurus christyi. He also obtained specimens of many rare West African forms in the same collection, thus adding considerably to our knowledge of the distribution of these species.

During the War, in spite of official duties, Dr. Christy still continued to collect, and sent home a very fine collection of fish from Mesopotamia. After the War he conducted two very important expeditions, one to Lake Nyasa and one to Lake Tanganyika, where he collected a great quantity and variety of fishes. These collections have proved to be some of the most important that have ever been received by the Natural History Museum, and the number of new species already described is very great; in one genus alone the species have been multiplied by six since Dr. Christy's collection has been worked out. The work in connexion with these collections is still continuing and many new forms doubtless remain to be described.

Medical science has lost a very able man in the death of Dr. Christy, and zoological science has lost one of its keenest collectors and most painstaking observers.

\section{Mr. L. G. Sutron}

The death of Mr. Leonard Goodhart Sutton, in his sixty-ninth year, took place somewhat suddenly at his residence, "Hillside", Reading, on June 13. Mr. Sutton was a grandson of the founder, and at the time of his death senior partner, of the worldfamous firm of Sutton and Sons. He was educated at Wellington College, and later went to the Royal Agricultural College, Cirencester, where he became particularly interested in the botany of grasses, of which group of plants he had a wide and accurate knowledge. After leaving Cirencester, Mr. Sutton spent two years in Germany, devoting himself to the study of the methods of seed production. On returning to England he entered the firm as a

$$
\text { No. 3272, VoL. 130] }
$$

